Нестеренко Д. М., магістр Пархоменко О. С., к.е.н., доцент

Харківський наиіональний університет імені В. Н. Каразіна м. Харків, Украӥна

DOI: https://doi.org/10.30525/978-9934-26-068-1-33

\title{
СУЧАСНІ ТЕНДЕНЦІЇ ФІНАНСОВОГО ЗАБЕЗПЕЧЕННЯ ДІЯЛЬНОСТІ ПІДПРИЕМСТВ В УКРАЇНІ
}

Будь-яка господарська діяльність підприємства здійснюється за умови наявності потоку грошових коштів, використання яких представлено у вигляді витрат, а надходження часто розглядаються як дохід, отриманих в результаті в їх використання та розподілу. Так однією з найважливіших проблем, що стримують активізацію ділової активності в Україні, є нестача коштів, що забезпечують стабільний грошовий потік. Фінансові ресурси підприємства $є$ не тільки основним інструментом для здійснення операційної діяльності, а й засобом, що підтримує розвиток 
виробничо-економічної системи і стимулює досягнення встановлених цілей і підвищення ефективність бізнесу.

Інвестиційне забезпечення фінансовими ресурсами є основою для подальшого розвитку будь-якого підприємства, так і для всієї економіки в масштабах країни. Відповідно до законодавства України інвестиції можуть здійснюватися за рахунок [1]:

- власних фінансових ресурсів інвестора (прибуток, амортизаційні відрахування, відшкодування збитків від аварій, стихійного лиха, грошові нагромадження i заощадження громадян, юридичних осіб тощо);

- позикових фінансових коштів інвестора (облігаційні позики, банківські та бюджетні кредити);

- залучених фінансових коштів інвестора (кошти, одержані від продажу акцій, пайові та інші внески громадян і юридичних осіб);

- бюджетних інвестиційних асигнувань;

- безоплатних та благодійних внесків, пожертвувань організацій, підприємств і громадян.

При аналізі структури джерел фінансування капітальних інвестицій в Україні $є$ очевидною прихильність підприємств використовувати власні кошти для здійснення інноваційноінвестиційної діяльність. Згідно із даними Державної служби статистики України в період з 2016-2019 рр. частка самофінансування в загальній структурі всіх капітальних інвестицій за джерелами фінансування коливається у межах від 68\% до 71\% (рис. 1) [2]. Орієнтація на використання цих джерел фінансування $\epsilon$ типовою для українського бізнесу. Така прихильність безпосередньо негативно впливає на можливості компаній стрімко зростати, тому що у разі обмежених обсягів фінансових ресурсів підприємства не мають змоги здійснити реалізацію значних інвестиційних проектів, в результаті чого багато експертів дотримуються думки про необхідність зміни тенденцій використання даного джерела фінансування на користь зовнішніх джерел [3, с. 180]. 
Слід зазначити, що незважаючи на обмежені можливості до зростання, цей підхід чинить сильний вплив на ризикову складову бізнесу, наприклад, під час кризи 2008 року саме компанії, що мали мінімальну залежність від зовнішніх джерел фінансування, показали найбільшу фінансову стійкість. Головною особливістю власних коштів в порівнянні із залученими та позиковими $\epsilon$ відсутність зобов'язань 3 виплати відсотків в будь-якій формі.

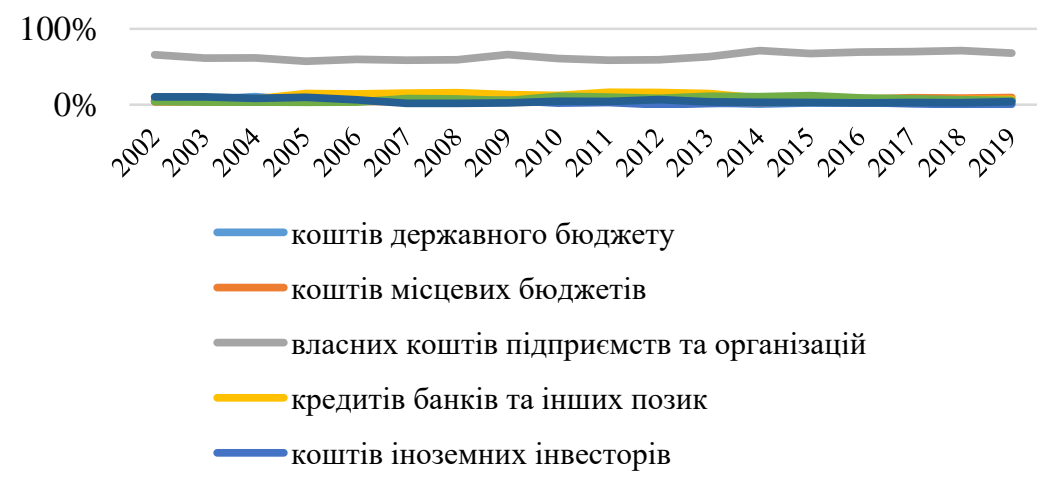

\section{Рис. 1. Структура капітальних інвестицій за різними джерелами фінансування за період 2002-2019 pp.}

Джерело: узагальнено за даними Державної служби статистики України [2]

Станом на кінець 2019 року загальний обсяг усіх капітальних інвестицій в Україні становив 643,949 млрд. грн., що на 7,82\% більше, ніж за попередній період 2018 року, та на 39,14\% більше ніж за 2017 рік (рис. 2). Така тенденція може бути наслідком стійкості фінансового стану українських підприємств, від якої значною мірою залежить досягнення визначеного результату. Таким чином підприємства, що отримали прибуток, мають можливість здійснити капітальні інвестиції за рахунок власних коштів. В умовах стагнації національної економіки i тривалого кризового періоду прибутку, отриманого вітчизняними 
підприємствами, може виявитися недостатньо для здійснення модернізації економіки і виходу з кризи.

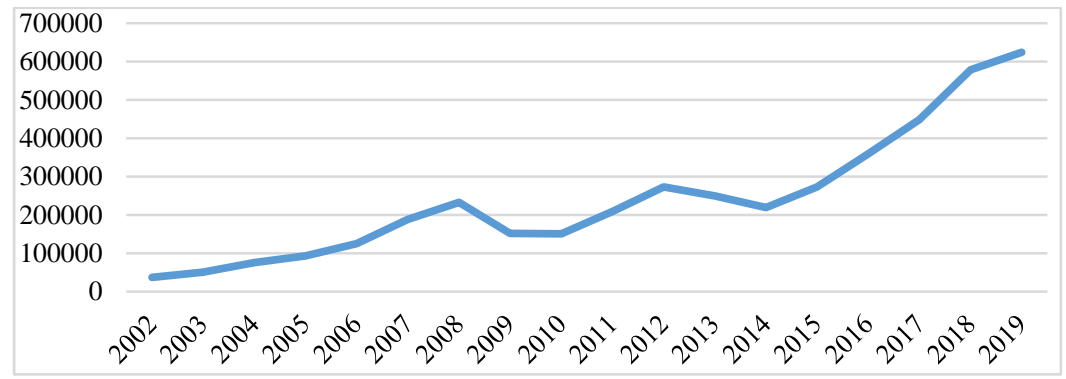

Рис. 2. Динаміка капітальних інвестицій в Україні у млн. грн. за період 2002-2019 pp.

Джерело: узагальнено за даними Державної Служби Статистики України[2]

Наступними за величиною питомої ваги залученими джерелами інвестиційних коштів в Україні в 2019-му році були кошти місцевих бюджетів (9,6\%), кредити банків (7\%) і кошти населення на будівництво житла $(5,6 \%)$. Якщо розглядати в динаміці, то можна помітити тенденцію на зменшення частки інвестицій за рахунок коштів населення на будівництво житла на 37\% за період 2016-2019 року, що говорить про зниження зацікавленості населення в інвестиції в будівництво первинного житла або зниженні зацікавленості організацій, що спеціалізуються на будівництві в залученні цього джерела фінансування, що може служити одним 3 показників стагнації галузі. Замість цього за той же період зріс обсяг капітальних інвестицій за рахунок місцевих бюджетів на $141 \%$ і за рахунок кредитів банків та інших позик на 76,28\%.

Можна зробити висновок, що протягом останніх років динаміка капітальних інвестицій в Україні є нестабільною, що насамперед пов'язано 3 поточною геополітичної ситуацією, 3 високою волатильністю національної валюти, розвиненою мережею корупційних схем, обтяжливою системою оподаткування підприємств і вразливою законодавчою базою. 
Результати проведеного аналізу стану капітального інвестування в Україні говорять про наявність значних проблем. Однак, вважаємо, що існує можливість позитивних змін у цій сфері, одним 3 проявів яких $є$ використання сучасних методів управління, що повинні спиратися на відповідні обліковоаналітичні інструменти.

\section{Література:}

1. Закон України «Про інвестиційну діяльність». URL: http://zakon.rada.gov.ua/laws/show/1560-12 (дата звернення: 23.03.2021).

2. Державна служба статистики України. Капітальні інвестиції за джерелами фінансування за 2010-2019 роки. URL: http://www.ukrstat.gov.ua/ operativ/operativ2007/ibd/iokjf/iokjf_u10-13_bez.htm (дата звернення: 23.03.2021).

3. В.В. Кірсанова, Л.О. Волощук, С.В. Філиппова. Обліково-аналітичні інструменти управління реальними інвестиціями підприємства у процесі інноваційного розвитку : монографія. Одеса : ФОП Бондаренко М.О., 2015. $198 \mathrm{c}$. 